\title{
Rotation of the Falklands microplate reassessed after recognition of discrete Jurassic and Cretaceous dyke swarms
}

\author{
P. Stone ${ }^{1}$, G. S. Kimbell ${ }^{2}$ \& P. C. Richards ${ }^{1}$ \\ 1. British Geological Survey, Murchison House, West Mains Road, Edinburgh \\ EH9 3LA, UK (e-mail: psto@bgs.ac.uk or pcr@bgs.ac.uk) \\ 2. British Geological Survey, Keyworth, Nottingham NG12 5GG, UK (e-mail: \\ gsk@bgs.ac.uk)
}

Key words:

Falkland Islands, South Atlantic, dykes, magnetic modelling, Gondwana breakup.

Running Head:

Rotation of Falklands microplate

\begin{abstract}
Recently acquired aeromagnetic data for the Falkland Islands has shown that previous interpretations of the dolerite dyke swarms are inadequate. In particular, most of the dykes previously described from West Falkland as forming a "north-south" swarm of Jurassic age are associated with a set of NE-SW linear magnetic anomalies that are entirely separate from another set of truly N-S anomalies. Very few dykes had been previously reported from East Falkland but the aeromagnetic survey demonstrates clearly that dykes of both the NE-SW and the N-S swarms are present. Ar-Ar age dating of East Falkland dykes has confirmed the Jurassic age of the NE-SW dykes but has established an early Cretaceous age for the N-S dyke swarm. The Jurassic dykes are generally considered a part of the regional Karoo-Ferrar magmatism linked to the initial break-up of Gondwana. We consider the Cretaceous dykes to be associated with the later opening of the North Falklands Basin during the early development of the South Atlantic Ocean. The Jurassic and Cretaceous dykes must respectively predate and post-date the microplate rotation envisaged in most models for the Falklands break-out from Gondwana. The shapes of the aeromagnetic anomalies associated with dykes from each of the swarms support the hypothesis that the early Jurassic dykes have experienced a pre-Cretaceous, clockwise microplate rotation of about $120^{\circ}$.
\end{abstract}

0000000000

A clastic sedimentary sequence ranging in age from Siluro-Devonian to Permian crops out across the Falkland Islands and is cut by numerous dolerite dykes (Fig.1). Until recently the dykes were regarded as exclusively of Jurassic age (Mussett \& Taylor 1994), but are now known to have been intruded during separate Jurassic and Cretaceous episodes of magmatism (Stone et al. 2008). Palaeomagnetic results from the Jurassic dykes (Taylor \& Shaw 1989) have been taken to support the proposition that the Falkland Islands form part of a microplate that during the break-up of Gondwana was rotated through $180^{\circ}$ from an original position adjacent to the east coast of South Africa (Adie 1952). Rotation has been described as either a late 
A comprehensive account of the Falkland Islands' geology is provided by Aldiss \& Edwards (1999). Of the sedimentary divisions, the Siluro-Devonian to Carboniferous quartzite, sandstone and mudstone of the West Falkland Group have the largest outcrop, covering most of the western archipelago, including the western of the two main islands, the eponymous West Falkland. In the eastern of the two main islands East Falkland - the West Falkland Group crops out in the north, whereas the south of East Falkland, and its smaller peripheral islands, is underlain by the tillite, mudstone and sandstone of the Carboniferous to Permian Lafonia Group. At the southern extremity of West Falkland the West Falkland Group rests unconformably on the Proterozoic crystalline basement of the Cape Meredith Complex, which has been dated at approximately 1100 -1000 Ma (Jacobs et al. 1999). Pre-Devonian, mafic dykes cut the Cape Meredith Complex (Thistlewood et al. 1997) with the widespread, polyphase swarms of Mesozoic dolerite dykes cutting the basement and all of the overlying sedimentary succession. Three discrete episodes of heating and cooling with the cooling phases occurring in the late Permian, early Jurassic and late Cretaceous - have been by described by Thomson et al. (2002) and linked to major changes in the plate tectonic setting of the Falklands.

This paper discusses the implications of recently-acquired aeromagnetic and geochronological (Ar-Ar: Stone et al. 2008) data for the rotational model of Falklands tectonics. The aeromagnetic survey was flown as part of a mineral exploration programme by Falklands Gold and Minerals Ltd. The Ar-Ar analyses were performed by R. Esser at the New Mexico Geochronological Research Laboratory. These results establish a more complex history of dyke intrusion than had been hitherto appreciated and here, in particular, we consider the newly-discovered, early Cretaceous dyke swarm. This additional element in the geological history of the Falklands has significance for the currently resurgent hydrocarbons exploration offshore, and also allows a better assessment of the widely accepted (though not universally so) regional model of microplate rotation.

\section{Disentangling the dyke swarms}

Dolerite dykes are numerous in West Falkland (Fig. 1a), where they were first noted in 1834 by Lt. (later Admiral Sir) Bartholomew Sulivan during the survey by HMS Beagle and reported by Charles Darwin (1846). Many more were discovered by Andersson (1907), Halle (1911) and Baker (1924), the last of whom reported dyke trends as varying from NNE-SSW around to WNW-ESE and suggested that they all shared a radial disposition emanating from a point somewhere at the southern end of Falkland Sound (Fig. 1a). This proposal was negated by the photo-interpretation of Greenway (1972) who identified up to 400 individual dykes on West Falkland, separated into three distinct but intersecting swarms: NNE-SSW dykes occurred mostly in the north and centre of the island whereas WNW-ESE dykes were confined to the south and the southwestern outlying islands; a more variable, localized pattern of dykes was identified in the extreme southwest, around Cape Orford. Subsequent work appeared to affirm Greenway's distinctions, with the two more widely seen 
trends being usually, if inaccurately, referred to as "north-south" and "east-west" dyke swarms (Taylor \& Shaw 1989; Mussett \& Taylor 1994; Mitchell et al. 1999).

In striking contrast to the situation in West Falkland, very few exposed dykes have been recorded in East Falkland. However, views on the distribution of dykes in the Falkland Islands were radically revised (Stone et al. 2008) in the light of the aeromagnetic survey flown by Falklands Gold and Minerals Ltd (FGML). The survey was flown at an elevation of $120 \mathrm{~m}$ above terrain and the $\mathrm{N}$-S flight lines were typically $500 \mathrm{~m}$ apart (with the spacing reduced to $250 \mathrm{~m}$ in parts of East Falkland and increased to $1000 \mathrm{~m}$ in parts of West Falkland); E-W tie lines were flown at $5 \mathrm{~km}$ spacings (or $2.5 \mathrm{~km}$ in parts of East Falkland). This data is illustrated by the residual magnetic field map in Figure 2, which features a number of well-defined, linear magnetic anomalies which we interpret as arising from mafic dykes; for clarity, these lineaments are extracted and annotated in Figure 3. Several features are noteworthy:

- The so-called "east-west" dykes in the southern part of West Falkland have a more complex geometry than previously supposed. One possibility is a partially radial disposition focused on a point to the west of the survey area, although some of the prominent dykes within this swarm have a more consistently E-W orientation and appear to cut across the general radial pattern. All of these dykes are normally magnetized.

- In the central and northern parts of West Falkland the previously defined "northsouth" swarm is resolved into two quite distinct components (Stone et al. 2008): one set of dykes does indeed trend north-south, but intersects an entirely separate dyke set trending NE-SW.

- The NE-SW trending dykes are present in both West and East Falkland, with their full extent in the East demonstrated for the first time by the aeromagnetic survey. In the West they appear to correlate to most of those previously described in detail from the "north-south" swarm. Most of the NE-SW dykes are reversely magnetised, although some local segments appear to have normal magnetisation. In the following discussion we refer to this swarm as the NE-SW dykes.

- The distinctive N-S (swinging northwards to NW-SE) set of approximately 40 dykes is spaced across both East and West Falkland and produces discrete linear magnetic anomalies unrelated to those from the other swarms. The dykes from this newly-identified swarm (Stone et al. 2008) are reversely magnetised in the east, but show both normal and reversed polarities in the west of the archipelago. In the following discussion we refer to this swarm as the N-S dykes.

The dense concentration of linear aeromagnetic anomalies, and by deduction of dykes, in some parts of West Falkland, particularly in the south, makes interpretation difficult. The situation is much clearer in East Falkland where the aeromagnetic data demonstrates the likely presence of an array of previously unsuspected dykes. There, the few established dykes, several close to the west (Falkland Sound) coast and one example farther east on Lively Island, correspond to NE-SW linear anomalies that prove them to have a much greater extent than previously recorded. No additional NE-SW dykes are proved by the aeromagnetic data for East Falkland, but clear and extensive north-south linear anomalies reveal the presence of a largely cryptic, northsouth dyke swarm spanning the full extent of the island and continuing westwards across West Falkland. Only two examples are known where dolerite dyke exposure is coincident with one of the N-S anomalies on East Falkland: Teal Creek and Pony's 
Pass (Fig. 3). Just to the east of the Darwin isthmus, Aldiss \& Edwards (1999) reported dolerite at two localities in the vicinity of Teal Creek. These localities lie on a (possibly compound) north-south anomaly, and subsequent ground investigations have proved dolerite outcrop along a $5 \mathrm{~km}$, north-south linear zone crossing Teal Creek, where an exposed dolerite dyke is $15 \mathrm{~m}$ across and is separated from a second, adjacent dyke by a narrow screen of country rock. Mineral exploration drilling by FGML has proved an unexposed continuation of this dyke a further $5 \mathrm{~km}$ northward. The second exposure of a north-south dyke coincident with a linear anomaly was revealed during development work at Pony's Pass Quarry, near Stanley. There, the dolerite dyke exposed in the quarry face is only about $2 \mathrm{~m}$ wide but from the magnitude of the associated anomaly seems likely to broaden vertically and/or horizontally. A third, but unexposed example of a north-south dyke was proved at Peat Banks, Lafonia (Fig. 3) by the mineral exploration drilling; this dyke is at least 5 $\mathrm{m}$ wide.

An offshore extension of the north-south dyke swarm is seen to the south-east of East Falkland where Barker (1999) derived north-south linear anomalies from the magnetic results of marine geophysical surveys. Barker tentatively associated the Lively Island dyke with the offshore swarm, but the new onshore data show that they are probably unrelated. In Fig. 3, Barker's results are plotted alongside the East Falkland terrestrial results, and the continuity of the N-S lineaments indicated by the two datasets is clear. In contrast, the Lively Island dyke (which lies outside the aeromagnetic survey area) has a possible along-strike counterpart farther to the north-east across East Falkland, although there is no evidence in the magnetic data of a direct, shallow linkage between these two features.

One striking feature of the north-south anomalies across both East and West Falkland is a variation in polarity, with some anomalies indicating that the presumed dyke source has normal magnetization whilst others indicate that magnetization is reversed. In the east, all the N-S dykes have a reverse magnetization, as do the offshore anomalies reported by Barker (1999), but westwards across East Falkland, and into West Falkland, dykes with normal magnetization become equally common. The same variation is seen in the NE-SW dyke swarm such that, in East Falkland, the Port Sussex dyke has reverse magnetization whereas normal magnetization is shown by the anomaly on the east side of the island, which lies on the projection of the Lively Island dyke. A reversed magnetic anomaly provides evidence of a stable reversed remanent magnetization that is stronger than the magnetization induced by the Earth's present field. A normal polarity magnetic anomaly does not automatically signify intrusion during a normal geomagnetic polarity interval as it could be due to the dominance of induced over remanent magnetisation. On current evidence it is thus possible, but not certain, that the N-S and NE-SW dyke swarms both span geomagnetic field reversals.

The relative ages of the different dyke swarms are difficult to assess from field evidence, although Aldiss \& Edwards (1999) concluded that in West Falkland the "north-south" swarm was probably younger than the "east-west" swarm. Where linear aeromagnetic anomalies intersect, the apparent order of superimposition is usually ambiguous. Even where dykes with different polarities intersect, no consistent sense of the intrusion sequence emerges. The possibility that dykes of different orientation 
formed parts of a conjugate set (Mussett \& Taylor 1994) can be discounted in view of their significantly different radiometric ages (discussed below) and compositions. The Jurassic radial dyke swarm in the south of West Falkland consists mostly of olivineclinopyroxene dolerites, the NE-SW Jurassic dykes are composed of dolerite containing both clino- and orthopyroxene, whilst the Cretaceous N-S dykes consist of glassy dolerite with only clinopyroxene in the ferromagnesian phase. Each of the dyke associations is geochemically distinct (Mitchell et al. 1999; Stone et al. 2008, see especially the supplementary material).

Not all the postulated dykes extend up to the bedrock surface. In places a linear magnetic anomaly crosses an area where exposure is good and there is no outcrop evidence of a dyke (for example the NE-SW anomaly crossing the eastern part of East Falkland that lies on the apparent north-eastward projection of the Lively Island dyke). Some of the anomalies in the south-western part of East Falkland, Lafonia, have a relatively long wavelength, indicating a significant depth of burial. The proving at Peat Banks coincides with one of several short-wavelength magnetic anomalies which are superimposed on a longer-wavelength $\mathrm{N}-\mathrm{S}$ positive magnetic lineament and occurs where it intersects a NE-SW negative lineament, suggesting that emplacement of the igneous rocks at shallower depth was facilitated by a structural intersection (Figs $2 \& 3$ ). The association of the shallow body with the N-S rather than the NE-SW dyke is confirmed by the positive polarity of the local magnetic anomaly and the geochemical composition of the dolerite dyke.

\section{The ages of the dyke swarms}

Jurassic ages for West Falkland dykes have been established by radiometric dating. Dykes from the vicinity of Cape Meredith (Fig. 1) have given K-Ar dates of 192 \pm 10 Ma (Cingolani \& Varela, 1976), and 176 \pm 7 and 162 \pm 6 Ma (Thistlewood et al., 1997); the latter two from "north-south" trending dykes that we assign to our NE-SW swarm. More precise Ar-Ar dates were reported by Mussett \& Taylor (1994): a dyke from the Cape Orford swarm gave 190 $44 \mathrm{Ma}$, an "east-west" dyke (from our radial swarm) gave $188 \pm 2 \mathrm{Ma}$, and a "north-south" dyke (from our NE-SW swarm) gave a maximum age of $193 \pm 4 \mathrm{Ma}$. These three Ar-Ar dates were regarded as indistinguishable within error, and have been taken to prove intrusion of all of the Falklands dykes at about 190 Ma.

A new Ar-Ar date from an East Falkland NE-SW dyke (Port Sussex, Figure 3) was provided by Stone et al. (2008) based on analyses of plagioclase separates. The age of 178.6 $\pm 4.9 \mathrm{Ma}$ is compatible with the Ar-Ar maximum age of c. $193 \mathrm{Ma}$ reported by Mussett \& Taylor (1994) from a NE-SW dyke in West Falkland, but is more closely aligned with the K-Ar date of c. $176 \mathrm{Ma}$ reported from a similarly orientated dyke at Cape Meredith by Thistlewood et al. (1997). In a regional context, the c. 178-179 Ma Ar-Ar date is also close to the c. 178-183 Ma peak of Karoo-Ferrar magmatism in South Africa and Antarctica (e.g. Duncan et al. 1997; Jourdan et al. 2005; Riley et al. 2005). There is a general consensus that this regional phase of early Jurassic magmatism, spanning the South African and Antarctic segments of Gondwana, marked the beginning of the break-up of that supercontinent. More specifically, Mitchell et al. (1999) considered that the Falklands Jurassic dykes marked a compositional overlap between the Karoo and Ferrar provinces with the "east-west" 
swarm of Karoo-type dolerite and the "north-south" (our NE-SW) swarm showing more affinity to Ferrar-type dolerite.

The N-S dyke from Pony's Pass, East Falkland (Fig. 3) was also dated by Stone et al. (2008). It gave an Ar-Ar age from plagioclase separates of 121.3 $\pm 1.2 \mathrm{Ma}$, which places intrusion of the N-S dykes within the Aptian stage of the early Cretaceous. An attempt to date the N-S dyke at Teal Creek was unsuccessful. Sills and/or lava flows identified in seismic sections across the offshore Falklands Plateau Basin (Fig.1b) have been assigned to the early Cretaceous on the basis of the presumed stratigraphy (Richards et al. 1996). They may represent the offshore equivalents of the N-S onshore dykes intruded into, or erupted upon, late Mesozoic strata. The recognition of onshore dykes of Aptian age adds some credence to the Richards et al. (1996) interpretation of an early Cretaceous age for the offshore volcanic rocks, and has implications for the way in which the stratigraphy of the Falkland Plateau is modelled. Strata previously assigned to the ?Jurassic - earliest Cretaceous interval may now be modelled as early Cretaceous, with the underlying succession, previously interpreted as ?Permo-Triassic, now possibly comprising sedimentary rocks as young as Jurassic.

The range of dates now available for onshore dykes from the Falkland Islands, and the definitive division of the various swarms made possible by the aeromagnetic data, together indicate a polyphase, Mesozoic intrusion history. The radial and Cape Orford swarms, both restricted to the southern part of West Falkland, would appear to have been intruded first, during the early Jurassic at about 188 - 190 Ma. The NE-SW dyke swarm was then intruded late in the early Jurassic at about 178 - 179 Ma. The NE-SW dykes are present in both West and East Falkland, and stitch across all of the main structural features of the islands, so precluding any significant tectonic movement subsequent to their intrusion. The only possible exception is movement on a putative, NE-SW fault in the vicinity of Falkland Sound, which was not covered by the aeromagnetic survey (Fig. 2). Several authors have proposed varying degrees of either dextral strike-slip movement (Marshall 1994; Thomas et al. 1997; Curtis \& Hyam 1998) or downthrow to the east (Aldiss \& Edwards 1999; Hyam et al. 2000) along a major Falkland Sound Fault, but the gap in survey coverage means that it is not possible to use the dyke anomaly pattern to constrain the amount or timing of any possible displacement.

\section{The rotational tectonic model for the Falkland Islands}

The Falkland Islands lie some $400 \mathrm{~km}$ east from the coast of South America with continental crust apparently in continuity. However, Falklands geology has been long recognised as having strong South African connections, with the Cape Meredith Complex, West Falkland Group and Lafonia Group correlating with the Natal Metamorphic Complex, the Cape Supergroup and the Karoo Supergroup respectively. The general similarities were appreciated by Halle (1911) and Baker (1924), and were discussed in terms of continental drift by Du Toit (1937), but they were dramatically reappraised in a seminal paper by Adie (1952). Adie proposed that during the opening of the South Atlantic Ocean, the Falklands continental block (or microplate in modern terms) had been rotated through $180^{\circ}$ from an original position adjacent to the east coast of South Africa. This prescient Gondwana reconstruction allowed structural continuity of the Cape Fold Belt and Karoo Basin into the Falklands area, and brought 
sedimentary transport directions into alignment. Subsequent modeling has shown that about $60^{\circ}$ of the postulated rotation can be explained by the opening of the South Atlantic, leaving a requirement for about $120^{\circ}$ of clockwise tectonic rotation (e.g. Marshall 1994; Mitchell et al. 1986).

From the perspective of the onshore geology, Adie's model remains compelling and has been refined in several more recent studies of Gondwana break-up geometry (e.g. Marshall 1994; Storey et al. 1999) and comparative stratigraphy (Trewin et al. 2002; Hunter \& Lomas 2003). However, the increasing knowledge of offshore geology resulting from oil exploration has thus far failed to generate any supporting evidence for rotation. Rather the opposite, with seismic interpretations suggesting that most major basins surrounding the Falklands have undergone initial east-west extension only, and share that orientation and tectonic history with adjacent basins in South America and south-west Africa (Richards et al. 1996). Against this background, the onshore Falklands dykes have taken on a pivotal role following the acquisition from them of palaeomagnetic results that support the rotational model (Mitchell et al. 1986; Taylor \& Shaw 1989).

All of the available palaeomagnetic data were acquired in West Falkland. Mitchell et al. (1986) reported hand-sampled palaeomagnetic results from 4 "north-south" dykes and baked shales adjacent to a large (but poorly exposed) "east-west" dyke. Taylor \& Shaw (1989) reported results from a much larger sampling programme that included 239 orientated drill cores taken from "north-south" and "east-west" dykes, and also from dykes of the Cape Orford swarm. Both studies were hampered by poor inland exposure but produced consistent results from the "north-south" suites that indicated a pole position far removed from the Mesozoic Apparent Polar Wander Path, to which it was best reconciled by rotation and restoration of the Falklands to a position east of South Africa, i.e. the Adie solution. Results from the "east-west" swarm were inconsistent and difficult to explain without further sampling. The Cape Orford swarm did not provide adequate data to allow determination of a specific palaeo-pole, but the data were sufficient to establish that it must be markedly different from that given by the "north-south" swarm. Some age difference between the dyke swarms therefore seemed likely although the radiometric dating results available at the time did not support this.

The more recent dating results presented by Stone et al. (2008) clarify the situation. Dykes of the Cape Orford swarm were intruded at about 190 Ma and so are older than those of the regional NE-SW swarm (previously described as "north-south"), which were intruded at about $178 \mathrm{Ma}$. Some rotation between the two intrusive episodes is therefore possible. The newly discovered Cretaceous dykes were intruded at about $121 \mathrm{Ma}$ and provide an absolute younger limit to the time available for rotation. If these dykes are indeed associated with the initial opening of the North Falkland Basin (Stone et al. 2008) then this younger limit is pushed back into the late Jurassic, though Thomson (1998) has proposed Valanginian (ca 136-140 Ma) rotation subsequent to initiation of the North Falklands Basin. If Thomson is correct, then the Cretaceous dykes relate to the later, post-rotation growth of the basin.

The identification of well-dated dykes that pre-date and post-date the putative rotation of the Falklands microplate provides an opportunity to test the rotational model. This would be done most rigorously by means of palaeomagnetic sampling, but as an 
initial step we have examined the forms of the magnetic anomalies revealed by the new airborne survey to see what insights they provide. Tectonic rotation would modify the orientation of the remanent (permanent) magnetisation acquired when a dyke originally cooled, influencing the shape of the magnetic anomaly detected over it. The analysis focused on dykes associated with negative magnetic anomalies in order to guarantee a dominant remanent magnetisation component. Fig. 4a shows the detail of the magnetic anomaly pattern on the west side of East Falkland, which includes effects due to both the NE-SW Saladero-Port Sussex dyke and a group of N$S$ dykes including that exposed at Teal Creek. All the magnetic anomalies are negative features and they are well-separated, avoiding the interference problems that are more prevalent on West Falkland. The image reveals that the anomalies over both dyke types are approximately symmetrical.

The synthetic Apparent Polar Wander Path of Besse \& Courtillot (2002) was used to estimate remanent magnetisation directions, assuming that the Falkland Islands have been rigidly attached to the South American plate. The predicted declination and inclination are $171^{\circ}$ and $+66^{\circ}$ respectively for reversed Aptian (120 Ma) magnetisation and $196^{\circ}$ and $+64^{\circ}$ respectively for reversed Karoo (180 Ma) magnetisation. $120^{\circ}$ was added to the declination of the Karoo vector to test for the influence of tectonic rotation. This is an approximation, because it does not allow for additional translations that may have occurred during microplate break-out, but it is judged to be adequate for the sensitivity trials discussed here. Another assumption that has been made is that the dykes are vertical; this is supported by the available outcrop evidence and by the fact that the observed magnetic anomalies maintain their linearity across areas of high topographic relief.

A symmetrical magnetic anomaly low is predicted when the Aptian magnetisation parameters are applied to a dyke with N-S orientation (Fig. 4b), and this is compatible with the observations (Fig. 4a). The asymmetric anomalies observed where the dykes adopt a more north-westerly trend (north-east side of Fig.2) are also predicted by a model based on Aptian magnetisation. It is, however, unlikely that the age of these dykes could have been inferred from the magnetic anomaly data alone. For example, a $\mathrm{N}-\mathrm{S}$ dyke with (unrotated) Karoo magnetisation also generates a relatively symmetrical anomaly (Fig. 4b). Incorporating post-Karoo tectonic rotation in a dyke with this trend does generate greater asymmetry (Fig. 4b), but it is doubtful whether this would have been regarded as diagnostic without the supporting geochronological evidence.

Figure 4c shows predicted magnetic anomalies over a NE-SW dyke with magnetisation acquired in Karoo times. If the dyke has not undergone tectonic rotation, an asymmetric anomaly is predicted with a distinctly higher south-eastern flank. If such rotation is assumed, the predicted anomaly is more symmetrical, with a slightly higher north-western flank. Inspection of individual magnetic profiles across the Saladero-Port Sussex dyke indicates shapes more consistent with the latter model. The magnetic anomaly data may therefore provide some support for the rotation hypothesis, although it is necessary to test the evidence more rigorously in order to confirm this. In particular, the influence of magnetisation induced by the Earth's present field needs to be investigated. Although such magnetisation must be weaker than the remanent magnetisation in dykes which generate negative anomalies, it may still be strong enough to have a significant influence on anomaly shape. 
Figure $4 \mathrm{~d}$ shows a model for a profile across the Saladero-Port Sussex dyke. The N-S survey lines are highly oblique to the $\mathrm{N} 30^{\circ} \mathrm{E}$ trend of the dyke, making them inappropriate for such modelling. The selected profile has been taken from an E-W tie-line in an area where interference from other anomaly sources is low; it provides the best resolution of anomaly shape available in the current dataset. The modelling was conducted using the Gravmag program (Pedley et al. 1993) and assumes twodimensional geometry. The magnetic properties adopted in the model are based on measurements made on dyke samples collected at Saladero by Hodgkinson (2002), which indicated a Königsberger or $\mathrm{Q}$ ratio (the ratio of remanent to induced magnetisation) of 2.6. Two dykes were sampled which both trended $\mathrm{N} 30^{\circ} \mathrm{E}$, and were about $1.5 \mathrm{~m}$ wide and $20 \mathrm{~m}$ apart; in one case the measured palaeomagnetic orientation was consistent with a rotated, reversed Karoo magnetisation but in the other it was not (data in digital appendix of Hodgkinson (2002)). The similarity in trend, composition and intensity of magnetisation of the two dykes suggests that the contrast in magnetisation direction cannot be explained by assigning one to the N-S swarm. The modelling results are, however, unambiguous: a much better fit to the observed anomaly is achieved if it is assumed that the Saladero-Port Sussex dyke is reversely magnetised and has undergone tectonic rotation (Fig. 4d).

This is an important result, but it has limitations, since the model profile is some distance from the location of the property measurements and the width of dyke necessary to generate the observed anomaly amplitude $($ c. $40 \mathrm{~m})$ is much greater than that proven at outcrop. In addition to geometrical factors (lateral and vertical variations in cumulative dyke width), the magnetic properties may be influenced by varying degrees of alteration. A broader range of models was assessed by devising a simple asymmetry parameter (based on the difference between the flanks of the predicted anomaly normalised with respect to its central minimum) and generating a set of theoretical solutions for this parameter spanning a full range of $\mathrm{Q}$ ratios and tectonic rotation angles. The asymmetry parameter was then estimated from the observed data along the length of the Saladero-Port Sussex dyke for comparison with these theoretical curves. There were limitations in the accuracy with which this could be done, because of the sampling bias mentioned above and interference from other sources of magnetic variation, an effect that was exacerbated by the relatively low amplitude of the anomalies observed over the dyke. After removal of long-wavelength $(>5 \mathrm{~km}$ ) variations, magnetic minima were identified on N-S flight lines in interference-free areas and the amplitudes of the anomaly flanks were estimated from neighbouring flight lines at locations along a line normal to the anomaly trend (nominally at $\pm 577 \mathrm{~m}$ along such a line relative to the anomaly minimum). The asymmetry estimates are thus susceptible to survey levelling errors but imaging (e.g. Fig. 4a) does indicate that such errors are very small. More than three-quarters of the sampled anomaly shapes formed a cluster ranging from symmetrical to the slight positive asymmetry displayed by the observed curve in Fig. 4d. The theoretical curves indicate that such shapes can be generated by Karoo-aged dykes in two ways: (i) by a combination of relatively strong reversed remanent magnetisation and positive tectonic rotation, or (ii) by an unrotated dyke with a Q-ratio in the range 1.1-1.5. The latter explanation is considered less likely on the basis of the contrast with the measured properties and the fact that the shapes of anomalies due to features with a $Q$ ratio in this range are relatively unstable. Anomaly shape becomes more stable at higher Q ratios and this is compatible with the along-strike consistency in the shape of 
the observed anomaly. The preferred interpretation is therefore that the form of the magnetic anomaly over the Saladero-Port Sussex dyke reflects the influence of clockwise tectonic rotation of the Falkland Islands. In principle it should be possible to use the anomaly shape to aid an attempt at quantifying the amount of rotation. In practice, the current data only allow this to be done in a very general way. For example for a $\mathrm{Q}$ ratio of 2.5 , the cluster of asymmetry values would admit clockwise rotations of between about $30^{\circ}$ and $180^{\circ}$; as $\mathrm{Q}$ increases, the range of solutions narrows to $60^{\circ}-150^{\circ}$.

\section{Implications for offshore geology and exploration}

The additional evidence, discussed above, for substantial rotation of a Falkland Islands microplate may necessitate a re-evaluation of offshore data, which Richards et al. (1996) utilised to suggest the presence of a rigid Falkland Plateau rather than a region containing a relatively small rotated micro-plate. No convincing evidence has yet been published from the offshore to support rotation of the Islands.

Our own observations of the extensive, modern offshore seismic dataset across the region indicate that there are numerous offshore basement features trending in a NWSE orientation. These features offset N-S normal faults in the North Falkland Basin north of the Islands, and form major northward-dipping thrust sheets across the Malvinas Basin to the west of the Islands and the Falkland Plateau Basin to the east of the Islands. These NW-SE oriented features have an identical orientation to the dominant Gondwanide (early Permian) structural grain, including northward-dipping thrust sheets visible onshore in the northern part of East Falkland. The fact that this structural grain, of seemingly regional extent, was imparted before the supposed rotation of a smaller-scale microplate remains to be explained in terms of microplate rotation, and the edges of any rotated block still need to be defined adequately in the offshore region.

The recognition of a set of dykes of Aptian age may also have profound implications for the stratigraphy of the Falkland Plateau Basin, where seismic records suggest the presence of sills (Richards et al. 1996). If these offshore sills were injected during the Aptian, in association with the onshore dyke intrusion at that time, then the deep, undrilled stratigraphy of the Falkland Plateau Basin may need to be re-evaluated. In particular, the potential stratigraphical position of early Cretaceous source rocks may need to be reassessed.

\section{Conclusions}

The recently acquired aeromagnetic data for the Falkland Island has shown that previous interpretations of the dyke swarms are inadequate. In particular, most of the dykes previously described as forming a "north-south" swarm of Jurassic age are associated with a set of NE-SW linear magnetic anomalies that are entirely separate from another set of truly north-south anomalies that spans (at least) West and East Falkland, and the offshore area to the south-east. Ar-Ar age dating has confirmed the Jurassic (178.6 $\pm 4.9 \mathrm{Ma})$ age of the NE-SW dykes but has established a Cretaceous $(121.3 \pm 1.2 \mathrm{Ma})$ age for the newly-recognised N-S dyke swarm. Most of the Jurassic, NE-SW dykes are reversely magnetised, although some local segments have normal 
magnetisation. The Cretaceous, N-S dykes are reversely magnetised in the east of the Falklands archipelago, but show both normal and reversed polarities in the west.

Very few dykes had been previously reported from East Falkland but we interpret the aeromagnetic survey results as demonstrating that many are in fact present. The same results lead us to believe that the spatial density of dykes in West Falkland is greater than has been previously appreciated. In the southern part of that island, the aeromagnetic data suggests that most of the "east-west" dykes of earlier accounts may be part of a radial swarm (about $80^{\circ}$ of arc can be seen), but a few cross-cutting and more prominent examples potentially form a younger suite. It is not entirely clear to which of these two possible dyke groups should be allocated the previously published Ar-Ar age of $188 \pm 2$ Ma.

A previously published, Ar-Ar maximum age of $193 \pm 4$ Ma for a "north-south" dyke from West Falkland is compatible with a more precise age of 178.6 \pm 4.9 Ma recently obtained from a NE-SW dyke in East Falkland. The palaeomagnetic results from a "north-south" dyke cited in support of tectonic rotation of the Falklands microplate (Mitchell et al. 1986; Taylor \& Shaw 1989) can, on the basis of the location, orientation and composition of the dyke analysed, be unequivocally associated with the Jurassic, NE-SW swarm.

The Jurassic dykes are generally considered a part of the regional Karoo-Ferrar magmatism linked to the initial break-up of Gondwana. We consider the Cretaceous dykes to be associated with the later opening of the North Falklands Basin during the early development of the South Atlantic Ocean. Hence there are now well-dated dykes that must pre-date and post-date the putative rotation of the Falklands microplate. This provides an opportunity to test definitively the rotational model: if rotation has occurred then the palaeomagnetic signature of the Falklands' Jurassic dykes will differ markedly from that of the Cretaceous dykes. An initial assessment based on the shapes of the aeromagnetic anomalies associated with dykes from each of the swarms indicates that there is a significant difference. The anomalies over the Cretaceous dykes are compatible with their current orientations. In contrast, the anomalies over the Jurassic dykes are better explained by a pre-Cretaceous, clockwise microplate rotation of about $120^{\circ}$.

\section{Acknowledgements}

Falkland Gold and Minerals Ltd made available data from the 2004 aeromagnetic survey; we particularly acknowledge the cooperation of the project manager, Derek Reeves. Field support was provided by the Department of Mineral Resources, Falkland Islands Government. This paper has benefitted for reviews by Don Aldiss, Richard Hodgkinson and Nick Richardson, and is published by permission of the Falkland Islands Government and the Executive Director, British Geological Survey (NERC). 


\section{References}

Adie, R. J. 1952. The position of the Falkland Islands in a reconstruction of Gondwanaland. Geological Magazine, 89, 401-410.

Aldiss, D. T. \& Edwards, E. J. 1999. The Geology of the Falkland Islands. British Geological Survey Technical Report, WC/99/10.

Andersson, J. G. 1907. Contributions to the geology of the Falkland Islands. Wissenschaftliche Ergebnisse der Schwedischen Sudpolar-expedition 1901-1903, 3 (Lief. 2), 38 pp.

Baker, H. A. 1924. Final Report on Geological Investigations in the Falkland Islands, 1920-1922. Government Printer, Stanley.

Barker, P. F. 1999. Evidence for a volcanic rifted margin and oceanic crustal structure for the Falkland Plateau Basin. Journal of the Geological Society, London, 156, 889900.

Besse, J. \& Courtillot, V. 2002. Apparent and true polar wander and the geometry of the geomagnetic field over the last $200 \mathrm{Myr}$. Journal of Geophysical Research, 107(B11), 2300, doi:10.1029/2000JB000050.

Cingolani, C. A. \& Varela, R. 1976. Investigaciones geologicas y geochronologicas en el extremo sur de la isla Gran Malvina, sector do Cabo Belgrano (Cabo Meredith), Islas Malvinas. In: Actas del sexto congreso Geologico Argentino, Buenos Aires, $457-$ 473.

Curtis, M. L. \& Hyam, D. M. 1998. Late Palaeozoic to Mesozoic structural evolution of the Falkland Islands: a displaced segment of the Cape Fold Belt. Journal of the Geological Society, London, 155, 115-129.

Darwin, C. 1846. On the geology of the Falkland Islands. Quarterly Journal of the Geological Society, London, 2, 267-274.

Duncan, R. A., Hooper, P. R., Rehacek, J., Marsh, J. S. \& Duncan, A. R. 1997. The timing and duration of the Karoo igneous event, southern Gondwana. Journal of Geophysical Research, 102, 18.127-18.138.

Du Toit, A. L. 1937. Our Wandering Continents. Oliver \& Boyd, Edinburgh \& London, 366 pp.

Greenway, M. E. 1972. The geology of the Falkland Islands. British Antarctic Survey Scientific Reports, 76, 42 pp.

Halle, T. G. 1911. On the geological structure and history of the Falkland Islands. Bulletin of the Geological Institution of the University of Uppsala, 11, 115-229. 
Hodgkinson. R. 2002. Structural studies in the Falkland Islands, South Atlantic. Unpublished $\mathrm{PhD}$ thesis, University of Birmingham.

Hunter, M. A. \& Lomas, S. A. 2003. Reconstructing the Siluro-Devonian coastline of Gondwana: insights from the sedimentology of the Port Stephens Formation, Falkland Islands. Journal of the Geological Society, London, 160, 459-476.

Hyam, D. M., Marshall, J. A. E., Bull, J. M. \& Sanderson, D. J. 2000. The structural boundary between East and West Falkland: new evidence for movement history and lateral extent. Marine and Petroleum Geology, 17, 13-26.

Jacobs, J., Thomas, R. J., Armstrong, R. A. \& Henjes-Kunst, F. 1999. Age and thermal evolution of the Mesoproterozoic Cape Meredith Complex, West Falkland. Journal of the Geological Society, London, 156, 917-928.

Jourdan, F., Féraud, G., Bertrand, H., Kampunzu, A. B., Tshoso, G., Watkeys, M. K. \& Le Gall, B. 2005. Karoo large igneous province: Brevity, origin and relation to mass extinction questioned by new ${ }^{40} \mathrm{Ar} /{ }^{39} \mathrm{Ar}$ age data. Geology, 33, 745-748.

Marshall, J. E. A. 1994. The Falkland Islands: a key element in Gondwana palaeogeography. Tectonics, 13, 499-514.

Mitchell, C., Ellam, R. M. \& Cox, K. G. 1999. Mesozoic dolerite dykes of the Falkland Islands: petrology, petrogenesis and implications for geochemical provinciality in Gondwanaland low-Ti basaltic rocks. Journal of the Geological Society, London, 156, 901-916.

Mitchell, C., Taylor, G. K., Cox, K. G. \& Shaw, J. 1986. Are the Falkland Islands a rotated microplate? Nature, 319, 131-134.

Mussett, A. E. \& Taylor, G. K. 1994. ${ }^{40} \mathrm{Ar}-{ }^{39} \mathrm{Ar}$ ages for dykes from the Falkland Islands with implications for the break up of southern Gondwanaland. Journal of the Geological Society, London, 151, 79-81.

Pedley, R.C., Busby, J.P. \& Dabek, Z.K. 1993. GRAVMAG user manual - interactive 2.5D gravity and magnetic modelling. British Geological Survey Technical Report WK/93/26/R.

Richards, P. C., Gatliff, R. W., Quinn, M. F., Williamson, J. P. \& Fannin, N. G. T. 1996. The geological evolution of the Falkland Islands continental shelf. In: Storey, B. C., King, E. C. \& Livermore, R. A. (eds) Weddell Sea Tectonics and Gondwana Break-up, Geological Society, London, Special Publications, 108, 105-128.

Riley, T. R., Leat, P. T., Curtis, M. L., Millar, I. L., Duncan, R. A. and Fazel, A. 2005. Early-Middle Jurassic dolerite dykes from Western Dronning Maud Land (Antarctica): identifying mantle sources in the Karoo Large Igneous Province. Journal of Petrology, 46, 1489-1524. 
Stone, P., Richards, P. C., Kimbell, G. S., Esser, R. P. \& Reeves, D. 2008. Cretaceous dykes discovered in the Falkland Islands: implications for regional tectonics. Journal of the Geological Society, London, 165, 1-4.

Storey, B. C., Curtis, M. L., Ferris, J. K., Hunter, M. A. \& Livermore, R. A. 1999. Reconstruction and break-out model for the Falkland Islands within Gondwana. Journal of African Earth Sciences, 29, 153-163.

Taylor, G. K. \& Shaw, J. 1989. The Falkland Islands: New palaeomagnetic data and their origin as a displaced terrane from southern Africa. In: Hillhouse, J. W. (ed.) Deep structure and past kinematics of accreted terranes. Geophysical Monographs, 50, 59-72.

Thistlewood, L., Leat, P. T., Millar, I. L., Storey, B. C. \& Vaughan, A. P. M. 1997. Basement geology and Palaeozoic-Mesozoic mafic dykes from the Cape Meredith Complex, Falkland Islands: a record of repeated intracontinental extension.

Geological Magazine, 134, 355-367.

Thomas, R.J., Jacobs, J. \& Weber, K. 1997. Geology of the Mesoproterozoic Cape Meredith Complex, West Falkland. In: Ricci, C.A. (ed.) The Antarctic Region: Geological Evolution and Processes, Terra Antarctica Publication, Siena. 21-30.

Thomson, K. 1998. When did the Falklands rotate? Marine and Petroleum Geology, 15, 723-736.

Thomson, K., Hegarty, K. A., Marshallsea, S. J. \& Green, P. F. 2002. Thermal and tectonic evolution of the Falkland Islands: implications for hydrocarbon exploration in the adjacent offshore region. Marine and Petroleum Geology, 19, 95-116.

Trewin, N. H., Macdonald, D. I. M. \& Thomas, C. G. C. 2002. Stratigraphy and sedimentology of the Permian of the Falkland Islands: lithostratigraphic and palaeoenvironmental links with South Africa. Journal of the Geological Society, London, 159, 5-19. 

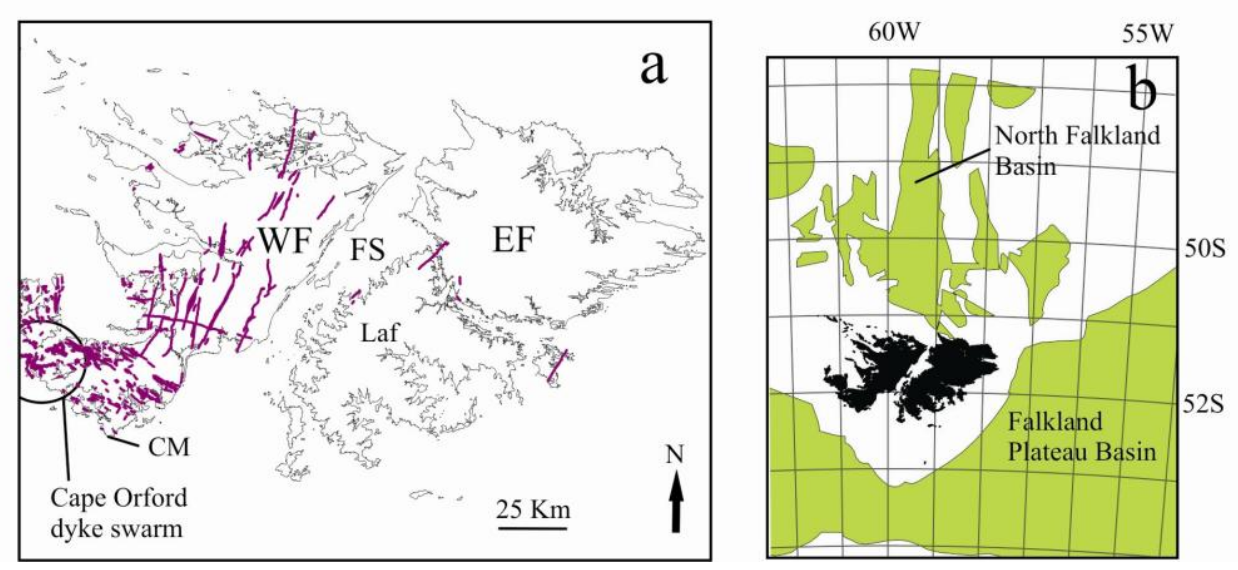

Fig. 1. The Falkland Islands showing: (a) The distribution of dykes (shown as purple lines) mapped prior to the survey described in this paper. CM, Cape Meredith; EF, East Falkland; FS, Falkland Sound; Laf, Lafonia; WF, West Falkland. (b) The distribution of Mesozoic to Tertiary sedimentary strata (shown green) in the surrounding offshore basins. 


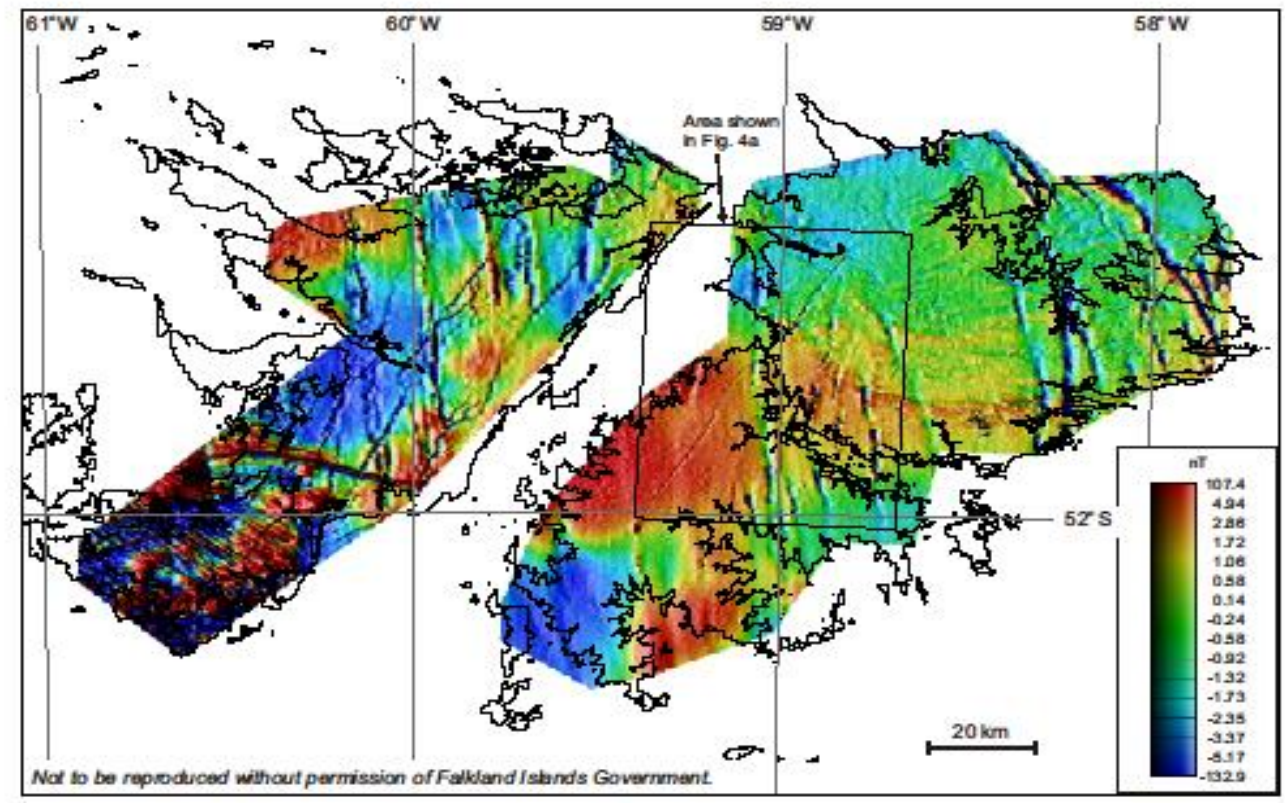

Fig. 2. Aeromagnetic image of the Falkland Islands, based on a residual field calculated by subtracting a $0.5 \mathrm{~km}$ upward continuation from the total magnetic field. Colour shaded-relief image with equal colour area and illumination from the west. The survey comprised N-S flight lines at a typical spacing of $0.5 \mathrm{~km}$ and E-W tie lines at a spacing of $5 \mathrm{~km}$; the flying height was $120 \mathrm{~m}$ above terrain. 


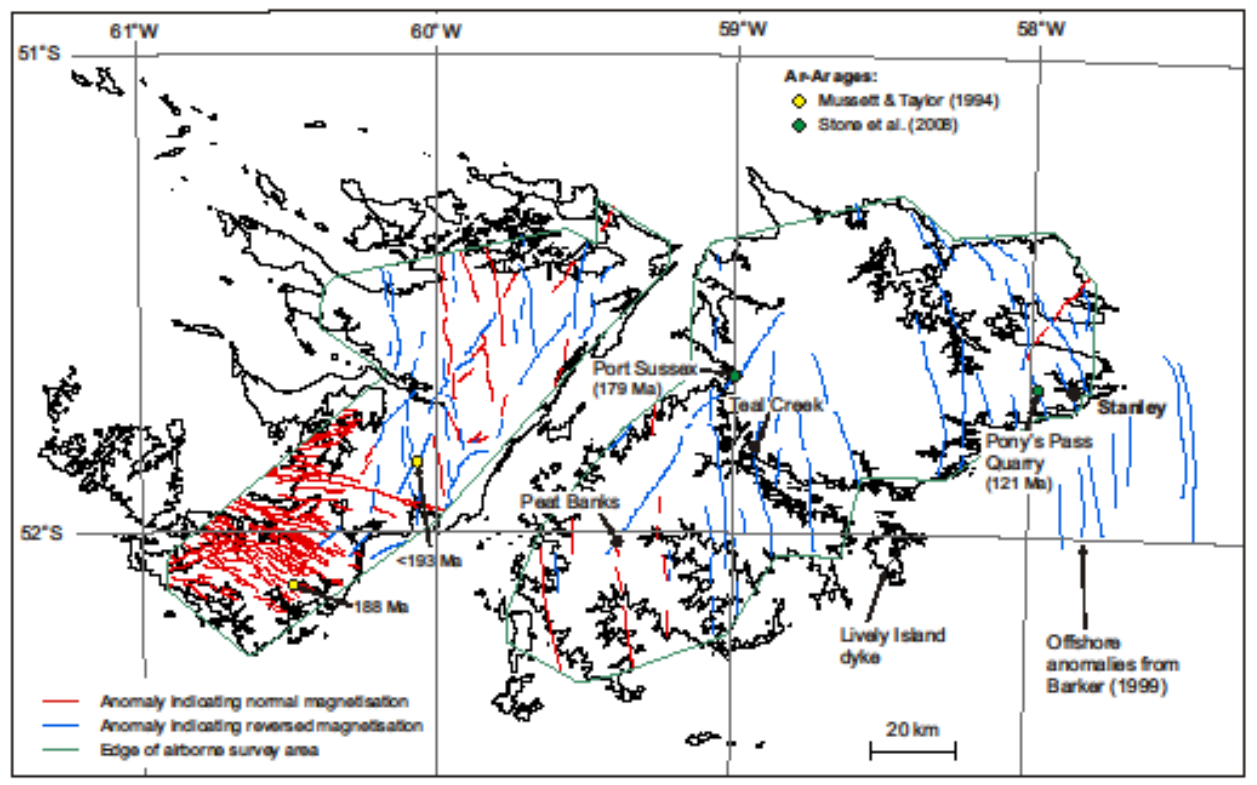

Fig. 3. Axes of linear magnetic anomalies interpreted to be caused by igneous dykes. Interpreted from various transforms of the aeromagnetic survey data illustrated in Fig. 2 and from marine magnetic surveys from Barker (1999). 

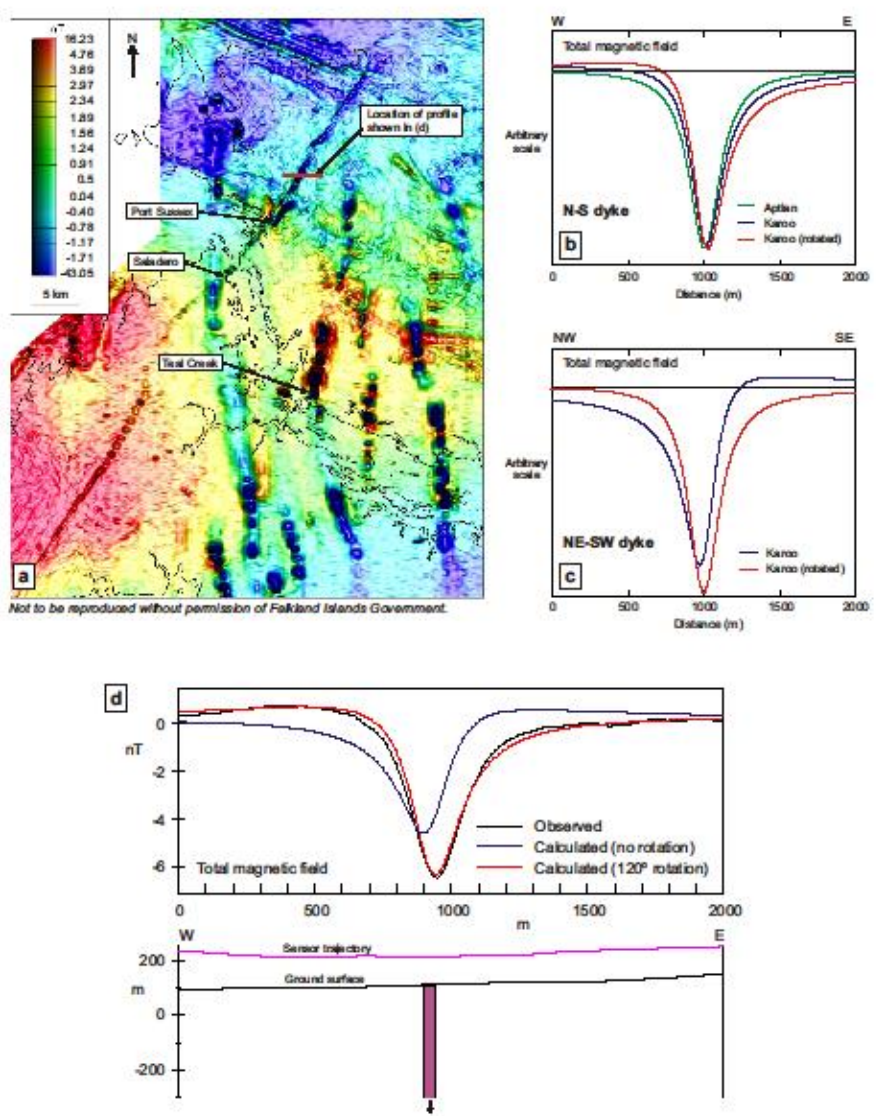

Fig. 4. (a) Residual magnetic anomalies over the west side of East Falkland. Same dataset as employed in Fig. 2, but with vertical illumination. The separation of some linear features into a series of local 'bulls-eyes' is typically due to sampling limitations rather than geological factors. (b) Predicted magnetic anomaly shapes over a N-S vertical dyke with magnetisation acquired at the times indicated. Arbitrary vertical scale; horizontal black line is the zero axis. (c) Influence of $120^{\circ}$ clockwise tectonic rotation on predicted magnetic anomaly shapes over a (currently) NE-SW vertical dyke which acquired its magnetisation in Karoo times. (d) Model for a magnetic profile across the Saladero - Port Sussex dyke (location shown in (a)). Magnetic susceptibility $=0.0022 \mathrm{SI}$; remanent intensity $=0.135 \mathrm{~A} / \mathrm{m}$ (after Hodgkinson 2002). Horizontal distances have been corrected to allow for the fact that the survey line does not cross the dyke orthogonally and a linear regional gradient of $-0.286 \mathrm{nT} / \mathrm{km}$ has been removed from the observed profile. 